\title{
The fish bone remains
}

\author{
Geoffrey Clark \\ Archaeology and Natural History, The Australian National University \\ Katherine Szabó \\ Archaeology and Natural History, The Australian National University
}

\section{Introduction}

Fisheries are a fundamental part of Remote Oceanic economies and lifeways, used for different types of fishing, invertebrate capture and collection, and the gathering of marine plants. Where no bones or calcareous parts remain, these activities are invisible to archaeologists, but modern studies of marine exploitation in Fiji and elsewhere in the Pacific (e.g. Rawlinson et al. 1994; Dalzell et al. 1996) indicate that a good portion of activities should leave traces in the archaeological record. As with marine mollusca, tropical Indo-Pacific fish species diversity is high. However unlike the mollusca, our inability to identify remains beyond the family level limits our ability to talk in any sensitive manner about ecology, niche exploitation, or often capture techniques. Nevertheless, through attention to ethnographic strategies and generalised family ecology, archaeologists have attempted to gain insight into prehistoric fishing strategies (e.g. Coutts 1975; Kirch and Dye 1979; Butler 1994), and we continue to build on this approach here, drawing in modern studies of subsistence and artisanal fishing in Fiji and elsewhere.

In a review of fish assemblages recovered from Lapita sites, Butler (1988:109-110) highlighted the dominance of inshore fish taxa by eight families (Serranidae, Lutjanidae, Lethrinidae, Labridae, Scaridae, Acanthuridae, Balistidae, Diodontidae), which accounted for more than $85 \%$ of archaeological fish remains. The predominance of these taxa has been used to characterise Lapita fishing as 'near shore' or 'inshore' (Green 1976, 1986; Kirch and Dye 1979; Kirch and Yen 1982; Kirch 1988). Despite the focus on inshore families, Butler (1994) argued there were important differences between the fishing strategies of Lapita groups in Near Oceania and those in Remote Oceania, including Fiji. In particular, fish assemblages in western Lapita 
sites such as Mussau indicated a generalised fishing strategy involving angling for carnivores and a range of techniques, such as traps, netting, spearing and poisoning, to capture herbivores/ omnivores. In Remote Oceania, Lapita fishing concentrated on herbivore/omnivore families and capture strategies other than angling. Further afield, early Austronesian fishing at the Bukit Tengkorak site in Sabah, Borneo Island, had a pattern similar to that of Lapita fishing in Remote Oceania: a focus on inshore herbivores/omnivores taken with nets, traps, poison and spears; the secondary importance of angling to catch Labridae and some species of Lethrinidae and Serranidae; and the relative unimportance of fishing in the pelagic zone with a hook or trolling lure (Ono 2003).

In contrast, fish remains from the Naigani Lapita site in Fiji, analysed by Hawkins (2000), had an atypical emphasis on reef-edge/reef-flat families, with the top five taxa consisting of Lethrinidae, Scaridae, Serranidae, Lutjanidae and Diodontidae. Three of the five taxa are carnivores that can be taken by angling, suggesting an emphasis on hook and line fishing, although no fish hooks or lure parts were found at the site (Best 1981; Hawkins 2000). The possibility that Lapita fishing strategies in Remote Oceania were flexible and able to be tailored to a local environment is supportive of a 'generalist' subsistence colonising strategy (Dye and Steadman 1990) in which a range of basic techniques were suitable for fishing a variety of inshore environments. Such flexibility suggests the pelagic zone could also have been used in Lapita times (see Szabó and Summerhayes 2002:95; Szabó 2007). Burley and Shutler (2007) record rotating and jabbing shell fish hooks from early sites in Tonga, along with a composite trolling lure suitable for capturing pelagic species made in Trochus shell, which is dated by a charcoal determination to $2620 \pm 50$ BP (CAMS 41531). Szabó (2007) records a near-identical Trochus niloticus lure shank of presumed Lapita age from Bourewa, Fiji.

Allen (1992:448-450) considers that Lapita subsistence patterns were not structurally different from those of post-Lapita Polynesian groups, but for Fiji it has been difficult to evaluate the variability of Lapita fishing in the archipelago, as well as the possibility of a post-Lapita change in fish-capture strategies due to technological developments and/or environmental factors. In this chapter, we present fish-bone identifications from six EPF sites (Figure 112) and consider prehistoric fish-capture strategies based on the dietary preference of taxa and ethnographic observations of traditional fishing (Masse 1986; Ono 2003). Results are compared with other archaeological fish-bone assemblages from Fiji to assess capture methods during the colonisation phase and whether different fishing strategies were used in the post-Lapita era. The effect of different collection methods on a fish-bone assemblage is examined from the Votua Lapita site excavated with dry sieving in $4 \mathrm{~mm}$ and $6 \mathrm{~mm}$ mesh, and an assemblage recovered from the same site by wet sieving with $3 \mathrm{~mm}$ mesh. Fish bone was analysed from the sites of Natunuku, Navatu, Kulu Bay, Malaqereqere, Volivoli II and Votua (1996 and 2000 excavations). The six assemblages yielded a Minimum Number of Individuals (MNI) of 406 fish from a total of 5231 identified bones. Bones were identified using a reference collection at the Australian National University, and the Navatu assemblage was identified by B.F. Leach at the Archaeozoology Laboratory (Wellington, New Zealand). Fish bone was absent or present in only trace amounts at Volivoli III, Qaranioso II and III, Ugaga Island and Karobo, and was not analysed from those sites.

\section{Methodology}

Following Leach (1997), the term fish 'type' or 'taxon/taxa' will be used, rather than 'species', as the identification of EPF assemblages has been made to the family level (e.g. Leach 1986; Nagaoka 1994; Hawkins 2000). Identification of taxa was with diagnostic head bones and 


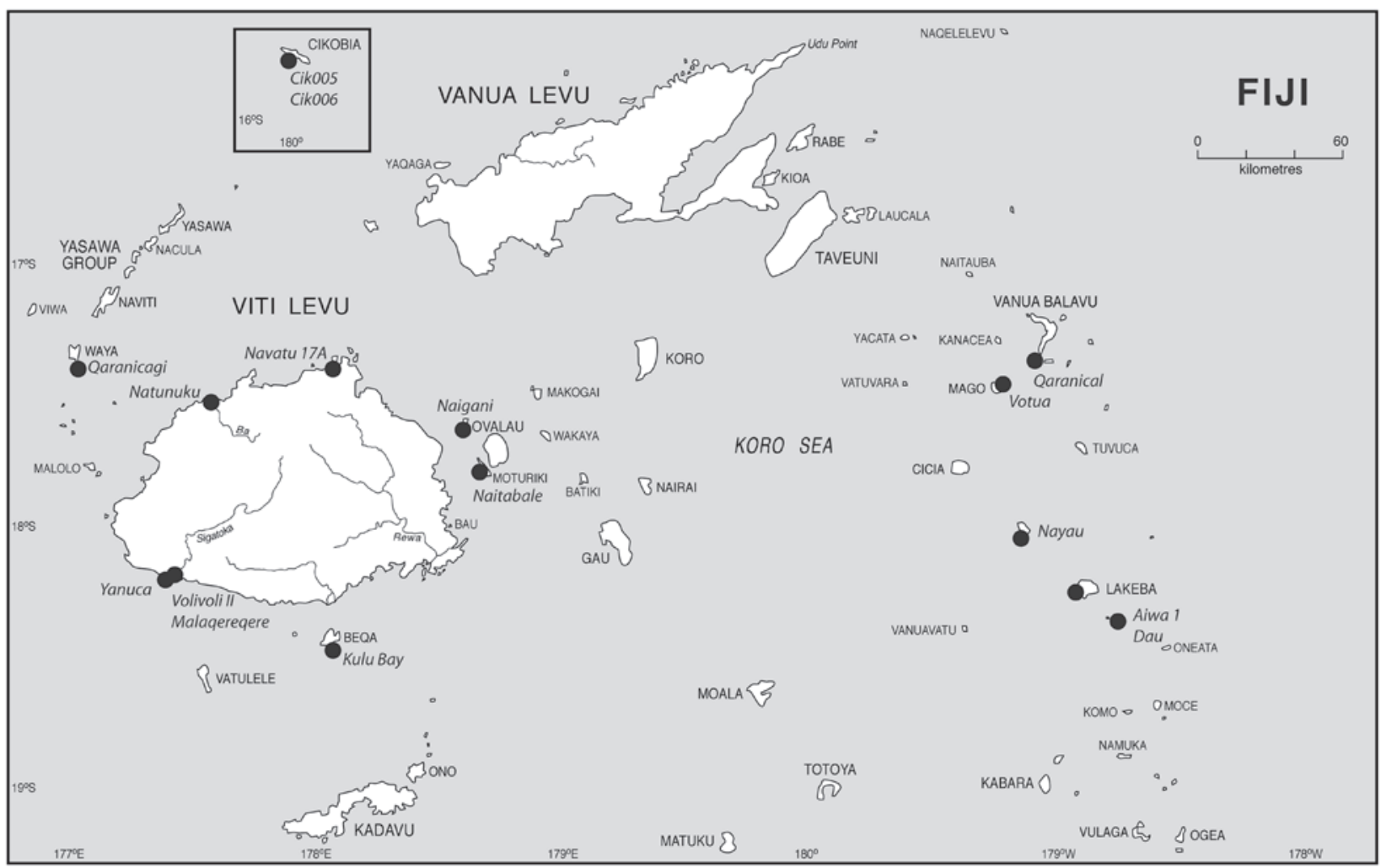

Figure 112. Map of Fiji showing the location of EPF and other fish-bone assemblages mentioned in the text.

'special' bones, following the methodology outlined in Leach $(1986,1997)$, using the fish reference collection in the Department of Archaeology and Natural History (ANU) established by Barnett (1978). Vogel (2005) has clearly demonstrated the utility of expanding the number of bones traditionally used for identification, identifying significant numbers of rarely or hitherto unrecorded families, such as Chaetodontidae (butterflyfishes) and Pomacentridae (damselfishes) for sites in south-central Polynesia. Unfortunately, the analyses presented here were largely completed before Vogel's study, and the identification of bones beyond the standard roster requires that the reference collection used has such additional bones present and correctly identified - a problem also encountered by Vogel (2005).

The abundance of different taxa in each assemblage was assessed by calculating NISP (Number of Identified Specimens) and MNI (Minimum Number of Individuals). The calculation of MNI follows the methodology of Chaplin (1971) as discussed in Leach (1986, 1997). In accordance with this, no attempt was made to increase the MNI results by adjusting for observed size difference in diagnostic head bones (e.g. Leach et al. 1997). In the comparison of site assemblages, the effects of different collection and aggregation strategies on the results are discussed, including assemblage sampling, and the effect of screen size and sieving method (e.g. Grayson 1984; Masse 1989).

An assessment of the relative importance of each taxon to the prehistoric diet is not attempted here, as the amount of food represented by a fish varies from species to species, and depends on the size of the individual fish caught, which could not be determined due to the absence of complete and measurable cranial bones (e.g. Leach et al. 1997). The ecological preference for each identified taxa along with the main types of capture technology have been discussed by several authorities (Kirch and Dye 1979; Butler 1994; Hawkins 2000; Ono 2003). Masse $(1986,1989)$ outlines the methodological problems of determining fish-capture technology in 
the Pacific where identification is at the family level. Within a family, a number of strategies are used to catch different species and often more than one technique is used to harvest a single species. The missionary Thomas Williams (1858[1985]:89-90) observed the diversity of Fijian fishing techniques in the 19th century:

Various means are employed for taking fish, including nets and a sort of weir formed like the creels and crab-pots used along the British coasts, and baited and secured in the same way. Another kind has two apertures; a third contrivance is an intricate fence, either fixed or portable. Stone pens, hooks, and fish spears, are in use throughout Fiji. Some drowsy fish of the shark family are taken by passing a noose over their heads, and a vegetable poison from a climbing glycine is employed to stupify smaller kinds. In some parts the rau is used, which is a fringe formed by winding split cocoa-nut leaves round a number of vines, to the length of hundreds or even thousands of feet. This being stretched in a straight line, the canoes to which the ends are attached approach until they meet, thus making a vast enclosure within which the fish are then speared or netted. One kind of net is used in the same way. The native seines are like our own, and are well made.

Despite the potential diversity of ethnographically documented fishing strategies, consideration of 'preferred' fish-capture technology is considered helpful in illustrating potential inter-site differences in capture technology, which can be tested to some extent by archaeological remains of fishing gear (sinkers, net weights and fish hooks). These approaches will be coupled here with studies and creel surveys derived from modern studies of Fijian fisheries (e.g. Rawlinson et al. 1994). While there are important technological differences, and introduced species such as jungle perch (Kublia rupestris) and tilapia (Oreochromis mossambicus) form an important component of the overall fisheries effort, these studies still highlight important links between fish behaviour and capture techniques, as well as giving a clear overview of important nearshore species available to Fijians.

\section{Kulu Bay}

At Kulu Bay 863 g of fish bone was recovered, with a NISP of 2907, including 15 identifiable taxa and a minimum of 240 individuals (Table 21). Based on MNI\%, seven taxa were responsible for $84 \%$ of the total - Scaridae (24.2\%), Labridae (15.0\%), Acanthuridae (10.4\%), Lethrinidae (9.6\%), Serranidae (9.2\%), Diodontidae (7.5\%) and Lutjanidae (7.5\%). Inspection of bone provenience shows that by weight, the amount of fish bone increased below $40 \mathrm{~cm}$ depth in all excavations, with the deepest excavation in square C11 returning quantities of fish bone down to $130-140 \mathrm{~cm}$ depth. This depth-density distribution is also seen with the Kulu Bay 1 shell sample (see Chapter 8).

The most commonly represented family in the Kulu assemblage was the Scaridae, followed by the Labridae and the Acanthuridae. The first-ranked taxon is a coral grazer that inhabits shallow reef waters. Masse (1986) argued that the most common method for harvesting herbivorous reef fish was by netting. However, in principle, any non-hook method is viable, with scarids being a major component of modern spearfish catches in Fiji and significant amounts also taken in gillnets (Gillett and Moy 2006:16). It should be noted that spearfishing has become both more commonly practised and able to quickly take a larger range of fish following the introduction of goggles, spearguns and scuba gear during the 20th century (Johannes 1981:67; Gillett and Moy 2006:11). Nevertheless, these observations, coupled with scarid ecology, demonstrate the effectiveness of spearing technologies for parrotfish. Adding the Diodontidae, Ostraciidae and Acanthuridae totals to the Scaridae, $46 \%$ of the identified MNI elements belong to taxa that are most likely to have been taken by non-hook technology (Table 22). 
Table 21. Identified fish families recovered from Kulu Bay.

\begin{tabular}{|c|c|c|c|c|}
\hline Family & NISP & NISP\% & MNI & MNI\% \\
\hline Acanthuridae & 27 & 0.9 & 25 & 10.4 \\
\hline Balistidae & 7 & 0.2 & 7 & 2.9 \\
\hline Carangidae & 3 & 0.1 & 2 & 0.8 \\
\hline Elasmobranchi & 2 & 0.1 & 2 & 0.8 \\
\hline Diodontidae & 70 & 2.4 & 18 & 7.5 \\
\hline Holocentridae & 2 & 0.1 & 2 & 0.8 \\
\hline Labridae & 78 & 2.7 & 36 & 15.0 \\
\hline Lethrinidae & 36 & 1.2 & 23 & 9.6 \\
\hline Lutjanidae & 30 & 1.0 & 18 & 7.5 \\
\hline Nemipteridae & 21 & 0.7 & 14 & 5.8 \\
\hline Ostraciidae & 14 & 0.5 & 10 & 4.2 \\
\hline Scaridae & 171 & 5.9 & 58 & 24.2 \\
\hline Thunnidae/Katsuwonidae & 2 & 0.1 & 2 & 0.8 \\
\hline Serranidae & 37 & 1.3 & 22 & 9.2 \\
\hline Sphyraenidae & 1 & 0.0 & 1 & 0.4 \\
\hline Unidentified & 2406 & 82.8 & 0 & 0.0 \\
\hline Total & 2907 & 100.0 & 240 & 100.0 \\
\hline
\end{tabular}

Table 22. Ethnographic capture methods and fish family representation (MNI\%) at Kulu Bay.

\begin{tabular}{|c|c|c|c|c|c|c|c|c|}
\hline Family & MNI\% & Baithook & Trolling lure & Net & Basket trap & Handspear & Poisoning & Preferred method \\
\hline Acanthuridae & 10.4 & $x$ & & $x$ & $x$ & $x$ & $x$ & Net \\
\hline Balistidae & 2.9 & $x$ & & $x$ & & $x$ & $x$ & Net \\
\hline Carangidae & 0.8 & $x$ & $x$ & $x$ & & $x$ & & Hook \\
\hline Elasmobranchi & 0.8 & $x$ & $x$ & $x$ & & $x$ & & Spear \\
\hline Diodontidae & 7.5 & & & $x$ & & $x$ & & Net \\
\hline Holocentridae & 0.8 & $x$ & $x$ & & & $x$ & & Hook \\
\hline Labridae & 15.0 & $x$ & & $X$ & $x$ & $x$ & $x$ & Hook \\
\hline Lethrinidae & 9.6 & $x$ & & $X$ & $x$ & & $x$ & Hook \\
\hline Lutjanidae & 7.5 & $x$ & $x$ & $X$ & & $X$ & $x$ & Hook \\
\hline Nemipteridae & 5.8 & $x$ & & & & & & Hook \\
\hline Ostraciidae & 4.2 & & & $x$ & & & & Net \\
\hline Scaridae & 24.2 & $x$ & & $x$ & $x$ & $x$ & $x$ & Net \\
\hline $\begin{array}{l}\text { Thunnidae/ } \\
\text { Katsuwonidae }\end{array}$ & 0.8 & $x$ & $x$ & & & $X$ & & Lure \\
\hline Serranidae & 9.2 & $x$ & & $X$ & & & & Hook \\
\hline Sphyraenidae & 0.4 & $x$ & $x$ & & & & & Lure \\
\hline
\end{tabular}


The labrids are the second-largest reef-fish family, and are diverse in habits, size and food preference (Masse 1986). The Balistidae are also complex in a Fijian context. Although often cited as herbivorous (e.g. Carcasson 1977:266), the most-targetted balistid in Fiji (Pseudobalistes flavimarginatus or yellowmargin triggerfish) (Carcasson 1977:268) is omnivorous, feeding on coral tips, gastropods, foraminiferans, crustaceans and tunicates (Froese and Pauly 2009), and nowadays is generally caught using a handline (see data in Rawlinson et al. 1994:50). It is possible that up to $54 \%$ of the Kulu fish assemblage could have been harvested using angling methods, but diverse techniques are used to capture fish species within all of these families, with even sphyraenids and emperors featuring in simple bamboo-spear catches by fishers wading in shallow water on the receding tide (Gillett and Moy 2006:15). Even the Spanish mackerel (Scomberomorus commerson), characteristic of modern Fijian troll-fisheries catches, is inquisitive and vulnerable to spearing (Rawlinson et al. 1994:415).

Ethno-archaeological studies of fishing (Kirch and Dye 1979; Masse 1986) suggest that a combined netting/angling strategy is a common fishing strategy among Pacific communities. A combined strategy using hook and non-hook technologies is suggested at Kulu Bay. While netting may well have been important at Kulu Bay, it is interesting to note the lack of species from the Siganidae (rabbitfishes) and Mugilidae (mullets) families, and the absence of the small mackerel Rastrelliger kanagurta (Scombridae), which feature very strongly in lagoon net catches in Fiji (Rawlinson et al. 1994:50; Dalzell et al. 1996:453). This may be an issue of identification or preservation, or may speak directly to the nature of the capture technologies employed.

The effects of element survival must also be considered at Kulu Bay, where the cultural materials have been redeposited. Of the surviving remains, the majority are the most robust bones in the fish skeleton, particularly the pharyngeal plates of the scarids and dorsal spines from large individuals. These are the main elements that have been assigned to a family. The dominance in the Kulu Bay assemblage of coral grazers might not accurately represent the prehistoric fish take, through under-representing individuals and taxa with small and fragile skeletal elements.

\section{Volivoli II}

From the identifiable fish-jaw elements recovered from Volivoli II, five taxa were identified. Members of the class Elasmobranchii (sharks, skates and rays) were identified from their distinctive vertebrae and teeth. The percentage of each taxa is given in Table 23, which shows that the small assemblage (NISP=106, MNI=9) also contained acanthurids, lethrinids, serranids and lutjanids. These three families (Acanthuridae, Lethrinidae and Serranidae) inhabit different niches and have different feeding strategies, suggesting that several capture strategies were employed (Butler 1994). Studies of fish feeding behaviour (Kirch and Dye 1979; Masse 1986; Butler 1994) indicate that the most effective way to catch acanthurids is with nets, spears or poison, as the taxa will not readily take a baited hook. Lethrinids and serranids are mainly caught by hook and line techniques. The different capture preferences for each taxon represented at Volivoli II are listed in Table 24. Due to the small size of the assemblage, it can only be suggested that a combination of non-hook and angling fishing strategies was employed. 
Table 23. Identified fish families recovered from Volivoli Il.

\begin{tabular}{lcccc}
\hline Taxa & NISP & NISP\% & MNI & MNI\% \\
\hline Acanthuridae & 6 & 5.7 & 3 & 33.3 \\
Elasmobranchi & 1 & 0.9 & 1 & 11.1 \\
Lethrinidae & 2 & 1.9 & 2 & 22.2 \\
Lutjanidae & 1 & 0.9 & 1 & 11.1 \\
Serranidae & 5 & 4.7 & 2 & 22.2 \\
Unidentified & 91 & 85.8 & 0 & 0 \\
Total & $\mathbf{1 0 6}$ & $\mathbf{1 0 0 . 0}$ & $\mathbf{9}$ & $\mathbf{1 0 0 . 0}$ \\
\hline
\end{tabular}

Table 24. Ethnographic capture methods and fish family representation (MNI\%) at Volivoli Il.

\begin{tabular}{lcccccccc}
\hline Family & MNI\% & Baithook & Trolling lure & Net & Basket trap & Handspear & Poisoning & Preferred method \\
\hline Acanthuridae & 33.3 & $X$ & & $X$ & $X$ & $X$ & $X$ & Net \\
Elasmobranchi & 11.1 & $X$ & $X$ & $X$ & & $X$ & & Spear \\
Lethrinidae & 22.2 & $X$ & & $X$ & $X$ & & $X$ & Hook \\
Lutjanidae & 11.1 & $X$ & $X$ & $X$ & & $X$ & $X$ & Hook \\
Serranidae & 22.2 & $X$ & & $X$ & & & & Hook \\
\hline
\end{tabular}

\section{Malaqereqere}

The Malaqereqere fish-bone assemblage had a NISP of 754 and an MNI of 54 from eight taxa. The site is a small coastal rock shelter that may have been used by fishing parties, resulting in a relatively high density of fish bone. The proportion of each taxon recovered from the Malaqereqere rock shelter is listed in Table 25, which shows the dominance of the Acanthuridae, comprising $37 \%$ of the total assemblage, followed by the Serranidae (14.8\%), Diodontidae $(14.8 \%)$ and Lethrinidae (13\%). The different capture methods for each of the taxa are listed in Table 26. As mentioned previously, acanthurids are algal grazers mainly taken by netting, diodontids are taken by netting or spearing, and serranids are often caught by hook and line techniques. The combination of the techniques of angling and netting suggests a mixed strategy of inshore fishing on and around the reef.

Table 25. Identified fish families recovered from Malaqereqere.

\begin{tabular}{lrccc}
\hline Taxa & NISP & NISP\% & MNI & MNI\% \\
\hline Acanthuridae & 20 & 2.7 & 20 & 37.0 \\
Balistidae & 1 & 0.1 & 1 & 1.9 \\
Diodontidae & 18 & 2.4 & 8 & 14.8 \\
Labridae & 3 & 0.4 & 3 & 5.6 \\
Lethrinidae & 8 & 1.1 & 7 & 13.0 \\
Lutjanidae & 8 & 1.1 & 5 & 9.3 \\
Scaridae & 2 & 0.3 & 2 & 3.7 \\
Serranidae & 13 & 1.7 & 8 & 14.8 \\
Unidentified & 681 & 90.3 & 0 & 0 \\
Total & $\mathbf{7 5 4}$ & $\mathbf{1 0 0 . 0}$ & $\mathbf{5 4}$ & $\mathbf{1 0 0 . 0}$ \\
\hline
\end{tabular}


Table 26. Ethnographic capture methods and fish family representation (MNI\%) at Malaqereqere.

\begin{tabular}{lcccccccc}
\hline Family & MNI\% & Baithook & Trolling lure & Net & Basket trap & Handspear & Poisoning & Preferred method \\
\hline Acanthuridae & 37.0 & $\mathrm{X}$ & $\mathrm{X}$ & $\mathrm{X}$ & $\mathrm{X}$ & $\mathrm{X}$ & Net \\
Balistidae & 1.9 & $\mathrm{X}$ & $\mathrm{X}$ & & $\mathrm{X}$ & $\mathrm{X}$ & Net \\
Diodontidae & 14.8 & & $\mathrm{X}$ & & $\mathrm{X}$ & & Net \\
Labridae & 5.6 & $\mathrm{X}$ & $\mathrm{X}$ & $\mathrm{X}$ & $\mathrm{X}$ & $\mathrm{X}$ & Hook \\
Lethrinidae & 13 & $\mathrm{X}$ & & $\mathrm{X}$ & $\mathrm{X}$ & & $\mathrm{X}$ & Hook \\
Lutjanidae & 9.3 & $\mathrm{X}$ & $\mathrm{X}$ & $\mathrm{X}$ & & $\mathrm{X}$ & $\mathrm{X}$ & Hook \\
Scaridae & 3.7 & $\mathrm{X}$ & & $\mathrm{X}$ & $\mathrm{X}$ & $\mathrm{X}$ & $\mathrm{X}$ & Net \\
Serranidae & 14.8 & $\mathrm{X}$ & & $\mathrm{X}$ & & & & Hook \\
\hline
\end{tabular}

\section{Navatu}

Fish bone from Trench B of the Navatu site was analysed by B.F. Leach, and the remains have been divided into two assemblages (Tables 27-30). The first assemblage contains the fish remains from Layer 1 and Layer 2, which date to around 600-500 cal. BP, while the second assemblage consists of the Layer 4 fish bone, dating to about 1000-1500 cal. BP. The sticky nature of the deposit at Navatu did not sieve well and the Navatu fish-bone assemblage is likely to over-represent large and robust elements compared with small and fragile bone remains. The upper (Layer 1 and Layer 2) and lower (Layer 4) assemblages have the same number of taxa, with individuals in the Scaridae and Lethrinidae families dominant by MNI\% in Layer 4, and the Tetraodontidae and Lethrinidae in Layers 1-2. A shark tooth from 80-90 cm depth was identified as mako (Isurus glaucus), and may represent shark fishing. In 19th century Fiji, sharks were caught by noosing, spearing or poisoning (Williams 1858[1985]:90). Although both of the Navatu fish-bone assemblages are small, the mixed netting-angling-spearing strategy (Table 30) suggests continuity in fish capture from the post-Lapita period through to the second millennium AD.

Table 27. Identified fish families recovered from Navatu (Layers 1 and 2).

\begin{tabular}{lcccc}
\hline Family name & NISP & NISP\% & MNI & MNI\% \\
\hline Balistidae & 1 & 5.9 & 1 & 10.0 \\
Diodontidae & 3 & 17.6 & 1 & 10.0 \\
Elasmobranchi & 1 & 5.9 & 1 & 10.0 \\
Labridae & 2 & 11.8 & 1 & 10.0 \\
Lethrinidae & 4 & 23.5 & 2 & 20.0 \\
Lutjanidae & 1 & 5.9 & 1 & 10.0 \\
Scaridae & 2 & 11.8 & 1 & 10.0 \\
Tetraodontidae & 3 & 17.6 & 2 & 20.0 \\
Total & $\mathbf{1 7}$ & $\mathbf{1 0 0 . 0}$ & $\mathbf{1 0}$ & $\mathbf{1 0 0 . 0}$ \\
\hline
\end{tabular}


Table 28. Ethnographic capture methods and fish family representation (MNI\%) at Navatu (Layers 1 and 2).

\begin{tabular}{lcccccccc}
\hline Family & MNI\% & Baithook & Trolling lure & Net & Basket trap & Handspear & Poisoning & Preferred method \\
\hline Balistidae & 10.0 & $X$ & & $X$ & & $X$ & $X$ & Net \\
Diodontidae & 10.0 & & & $X$ & & $X$ & & Net \\
Elasmobranchi & 10.0 & $X$ & $X$ & $X$ & & $X$ & & Spear \\
Labridae & 10.0 & $X$ & & $X$ & $X$ & $X$ & $X$ & Hook \\
Lethrinidae & 20.0 & $X$ & & $X$ & $X$ & & $X$ & Hook \\
Lutjanidae & 10.0 & $X$ & $X$ & $X$ & & $X$ & $X$ & Hook \\
Scaridae & 10.0 & $X$ & & $X$ & $X$ & $X$ & $X$ & Net \\
Tetraodontidae & 20.0 & & & $X$ & $X$ & $X$ & $X$ & Net \\
\hline
\end{tabular}

Table 29. Identified fish families recovered from Navatu (Layer 4).

\begin{tabular}{lcccc}
\hline Family name & NISP & NISP\% & MNI & MNI\% \\
\hline Diodontidae & 1 & 3.4 & 1 & 9.1 \\
Elasmobranchi & 4 & 13.8 & 1 & 9.1 \\
Lethrinidae & 5 & 17.3 & 2 & 18.2 \\
Lutjanidae & 1 & 3.4 & 1 & 9.1 \\
Scaridae & 12 & 41.4 & 4 & 36.3 \\
Tetraodontidae & 2 & 6.9 & 1 & 9.1 \\
Total & $\mathbf{2 9}$ & $\mathbf{1 0 0 . 0}$ & $\mathbf{1 1}$ & $\mathbf{1 0 . 0}$ \\
\hline
\end{tabular}

Table 30. Ethnographic capture methods and fish family representation (MNI\%) at Navatu (Layer 4).

\begin{tabular}{lcccccccc}
\hline Family & MNI\% & Baithook & Trolling lure & Net & Basket trap & Handspear & Poisoning & Preferred method \\
\hline Diodontidae & 9.1 & & & $X$ & & $X$ & & Net \\
Elasmobranchi & 9.1 & $X$ & $X$ & $X$ & & $X$ & & Spear \\
Lethrinidae & 18.2 & $X$ & & $X$ & $X$ & & $X$ & Hook \\
Lutjanidae & 9.1 & $X$ & $X$ & $X$ & & $X$ & $X$ & Hook \\
Scaridae & 36.3 & $X$ & & $X$ & $X$ & $X$ & $X$ & Net \\
Serranidae & 9.1 & $X$ & & $X$ & & & & Hook \\
Tetraodontidae & 9.1 & & & $X$ & $X$ & $X$ & $X$ & Net \\
\hline
\end{tabular}

\section{Natunuku}

The fish-bone assemblage from the Natunuku Lapita site (NISP=215) was compromised by its small size, high degree of fragmentation and general lack of identifiable elements (Table 31). The only family that could be firmly identified was the Scaridae. Elasmobranchii or cartilaginous fishes were represented in the deposits by small vertebrae, along with the pharyngeal plate of a diodont. The lack of fishing gear in the artefact assemblage from Natunuku (Davidson et al. 1990) could indicate that angling was not used at the site and that fish capture was with nets/ spears/traps/poison, but robust conclusions about the nature of Lapita fishing cannot be drawn from the Natunuku assemblage. 
Table 31. Identifiable elements in the Natunuku fish bone assemblage (NISP=215).

\begin{tabular}{|c|c|c|c|}
\hline Provenance & Taxa & Element & NISP \\
\hline TP1:0-10 & Unidentified & vertebrae & 3 \\
\hline TP1:0-10 & Unidentified & premaxilla & 1 \\
\hline TP1/2:0-10 & Unidentified & vertebrae & 1 \\
\hline TP1/2:0-10 & Unidentified & fragment & 1 \\
\hline TP1/2:10-20 & Unidentified & vertebrae & 1 \\
\hline TP1/2:20-30 & Unidentified & vertebrae & 4 \\
\hline TP2:0-10 & Unidentified & vertebrae & 2 \\
\hline TP2:10-20 & Elasmobranchi & tooth & 1 \\
\hline TP2/2: $0-10$ & Unidentified & vertebrae & 6 \\
\hline TP2/2: $0-10$ & Elasmobranchi & vertebrae & 1 \\
\hline TP2/2:10-20 & Unidentified & vertebrae & 4 \\
\hline Тр2/2:10-20 & Unidentified & fragments & 2 \\
\hline TP2/3: 0-10 & Unidentified & vertebrae & 2 \\
\hline TP2/3:10-20 & Unidentified & vertebrae & 1 \\
\hline T3/A3/Layer 2a & Unidentified & fragment & 1 \\
\hline T3/A3/Layer 2 & Unidentified & vertebrae & 2 \\
\hline T3/A4:10-20 & Elasmobranchi & vertebrae & 1 \\
\hline T3/A4:10-20 & Unidentified & quadrate & 1 \\
\hline T3/A4:20-30 & Unidentified & vertebrae & 1 \\
\hline T3/A4:20-30 & Unidentified & fragment & 1 \\
\hline $\mathrm{T} 3 / \mathrm{A5}: 0-10$ & Unidentified & vertebrae & 1 \\
\hline T3/A5:0-10 & Diodontidae & pharyngeal plate & 1 \\
\hline T3/A5:20-30 & Elasmobranchi & vertebrae & 2 \\
\hline Т3/A5:30-40 & Elasmobranchi & vertebrae & 1 \\
\hline T3/A5:30-40 & Scaridae & dentary & 1 \\
\hline T3/A6:10-20 & Scaridae & dentary & 1 \\
\hline T3/A6:10-20 & Unidentified & vertebrae & 5 \\
\hline T3/A6:20-30 & Unidentified & vertebrae & 1 \\
\hline T3/B5:10-20 & Elasmobranchi & vertebrae & 2 \\
\hline T3/B6:20-30 & Scaridae & premaxilla & 1 \\
\hline T3/B6:40-50 & Unidentified & vertebrae & 2 \\
\hline T3/B6:50-60 & Elasmobranchi & vertebrae & 1 \\
\hline T3/B6:50-60 & Unidentified & vertebrae & 4 \\
\hline Total & & & 60 \\
\hline
\end{tabular}




\section{Votua}

The Votua Lapita site was discovered in 1996 and test excavations in a shell midden (Area 1) and test pit (TP1) recovered small amounts of fish bone (Clark et al. 2001) from dry sieving of the clay sediments through $4 \mathrm{~mm}$ and $6 \mathrm{~mm}$ mesh. The possibility that a coarse collection strategy in 1996, necessitated by the nature of the deposits and available equipment, had led to the loss of faunal remains, especially of fish, from the Lapita deposit was tested in 2000 when Area 2 (1 $\mathrm{m} \times 4 \mathrm{~m}$ ) was excavated and all sediments were water sieved through $3 \mathrm{~mm}$ mesh. A low NISP of 16 representing an MNI of 11 from five taxa was found in the 1996 investigations (Tables 32-33), compared with a NISP of 1343 and MNI of 57 from six taxa in 2000 (Tables 34-36). A breakdown of identified taxa elements relative to the number of vertebra and spines is shown in Table 34. The two assemblages differ in the presence of individuals from the Lethrinidae and Monocanthidae families in Area 1/TP1 and Acanthuridae and Carangidae in Area 2, but both assemblages were dominated by scarids $(1996=54.5 \%, 2000=40.4 \%)$, and the number of taxa did not change significantly, in spite of the larger sample obtained in 2000 (Tables 32 and 34-35). Despite the significant difference in sample size, both of the Votua assemblages suggest a major focus on non-hook technologies, in tandem with some angling (Tables 33 and 36).

Artefacts from the Votua 2000 excavations support the view that angling was undertaken, as there were several fragments from small pearl-shell fish hooks (tab and shank), similar to those recorded by Best (1984:450) from early deposits on Lakeba (see Chapter 14 Appendix:Figure 155). Votua also contained pieces of coral abraded with semi-circular linear grooves that might have been used to shape the shaft of arrows or spears for use in fishing (Best 1984:445; Chapter 14 Appendix:Figure 159). The diameter of nine coral grooves ranged from $5.8 \mathrm{~mm}$ to 11.8 $\mathrm{mm}$, and traditional wooden arrow shafts used today have a diameter of $6.5 \mathrm{~mm}$ to $9.2 \mathrm{~mm}$. At Votua, fishing with spears/bow and arrow was a potentially important capture strategy during the Lapita era.

Table 32. Identified fish families recovered from Votua 1996 excavations.

\begin{tabular}{lcccc}
\hline Family & NISP & NISP\% & MNI & MNI\% \\
\hline Labridae & 1 & 6.3 & 1 & 9.1 \\
Lethrinidae & 4 & 25.0 & 2 & 18.2 \\
Monocanthidae & 1 & 6.3 & 1 & 9.1 \\
Scaridae & 7 & 43.7 & 6 & 54.5 \\
Serranidae & 3 & 18.7 & 1 & 9.1 \\
Total & $\mathbf{1 6}$ & $\mathbf{1 0 0 . 0}$ & $\mathbf{1 1}$ & $\mathbf{1 0 0 . 0}$ \\
\hline
\end{tabular}

Table 33. Ethnographic capture methods and fish family representation (MNI\%) at Votua (Area 1 and TP1).

\begin{tabular}{lcccccccc}
\hline Family & MNI\% & Baithook & Trolling lure & Net & Basket trap & Handspear & Poisoning & Preferred method \\
\hline Labridae & 9.1 & $X$ & $X$ & $X$ & $X$ & $X$ & Hook \\
Lethrinidae & 18.2 & $X$ & $X$ & $X$ & & $X$ & Hook \\
Monocathidae & 9.1 & & $X$ & $X$ & $X$ & $X$ & Net \\
Scaridae & 54.5 & $X$ & $X$ & $X$ & $X$ & $X$ & Net \\
Serranidae & 9.1 & $X$ & $X$ & & & & Hook \\
\hline
\end{tabular}


Table 34. Fish bone recovered from Votua 2000 excavations (Area 2, Squares 1-4).

\begin{tabular}{lcccccccccc}
\hline Spit & ID NISP & ID (g) & $\begin{array}{c}\text { Vertebra } \\
(\text { NISP) }\end{array}$ & $\begin{array}{c}\text { Vertebra } \\
(\mathbf{g})\end{array}$ & $\begin{array}{c}\text { Spine } \\
(\text { NISP) }\end{array}$ & $\begin{array}{c}\text { Spine } \\
(\mathbf{g})\end{array}$ & $\begin{array}{c}\text { Residue } \\
(\text { NISP) }\end{array}$ & $\begin{array}{c}\text { Residue } \\
(\mathbf{g})\end{array}$ & $\begin{array}{c}\text { NISP Total Spit weight } \\
(\mathbf{g})\end{array}$ \\
\hline $0-10$ & 5 & 5.4 & 23 & 5.1 & 13 & 3.2 & 27 & 4.0 & 68 & 17.7 \\
$10-20$ & 8 & 5.3 & 58 & 14.2 & 29 & 2.5 & 76 & 10.0 & 171 & 32.0 \\
$20-30$ & 11 & 5.2 & 52 & 23.0 & 56 & 5.6 & 93 & 12.8 & 212 & 46.6 \\
$30-40$ & 16 & 9.0 & 70 & 16.9 & 103 & 14.2 & 126 & 21.9 & 315 & 62.0 \\
$40-50$ & 20 & 6.9 & 73 & 23.5 & 95 & 9.4 & 166 & 19.6 & 354 & 59.4 \\
$50-60$ & 12 & 9.0 & 71 & 22.3 & 27 & 3.6 & 87 & 10.5 & 197 & 45.4 \\
$60-70$ & 1 & 2.4 & 12 & 3.0 & 3 & 0 & 10 & 1.2 & 26 & 6.6 \\
Total & $\mathbf{7 3}$ & $\mathbf{2 7 . 3}$ & $\mathbf{3 5 9}$ & $\mathbf{1 0 8 . 0}$ & $\mathbf{3 2 6}$ & $\mathbf{3 8 . 5}$ & $\mathbf{5 8 5}$ & $\mathbf{8 0 . 0}$ & $\mathbf{1 3 4 3}$ & $\mathbf{2 6 9 . 7}$ \\
\hline
\end{tabular}

Table 35. Identified fish families recovered from Votua 2000 excavations.

\begin{tabular}{lrrrr}
\hline Family & NISP & NISP $\%$ & MNI & MNI\% \\
\hline Acanthuridae & 14 & 1.1 & 12 & 21.0 \\
Carangidae & 5 & 0.4 & 3 & 5.3 \\
Diodontidae & 40 & 3.0 & 5 & 8.8 \\
Labridae & 10 & 0.7 & 8 & 14.0 \\
Scaridae & 42 & 3.1 & 23 & 40.4 \\
Serranidae & 13 & 1.0 & 6 & 10.5 \\
Unidentified & 1219 & 90.7 & 0 & 0 \\
Total & $\mathbf{1 3 4 3}$ & $\mathbf{1 0 0 . 0}$ & $\mathbf{5 7}$ & $\mathbf{1 0 0 . 0}$ \\
\hline
\end{tabular}

Table 36. Ethnographic capture methods and fish family representation (MNI\%) at Votua 2000 excavations (Area 2, Squares 1-4).

\begin{tabular}{lcccccccc}
\hline Family & MNI\% & Baithook & Trolling lure & Net & Basket trap & Handspear & Poisoning & Preferred method \\
\hline Acanthuridae & 21.0 & $\mathrm{X}$ & & $\mathrm{X}$ & $\mathrm{X}$ & $\mathrm{X}$ & $\mathrm{X}$ & Net \\
Carangidae & 5.3 & $\mathrm{X}$ & $\mathrm{X}$ & $\mathrm{X}$ & & $\mathrm{X}$ & & Hook \\
Diodontidae & 8.8 & & & $\mathrm{X}$ & & $\mathrm{X}$ & & Net \\
Labridae & 14.0 & $\mathrm{X}$ & $\mathrm{X}$ & $\mathrm{X}$ & $\mathrm{X}$ & $\mathrm{X}$ & Hook \\
Scaridae & 40.4 & $\mathrm{X}$ & $\mathrm{X}$ & $\mathrm{X}$ & $\mathrm{X}$ & $\mathrm{X}$ & Net \\
Serranidae & 10.5 & $\mathrm{X}$ & & $\mathrm{X}$ & & & & Hook \\
\hline
\end{tabular}

\section{Prehistoric fishing in Fiji}

A hierarchical cluster analysis of family MNI\% was made with SPSS (16.0) to examine relationships among the EPF fish assemblages (Figure 113). The two south-coast Viti Levu assemblages of Volivoli II and Malaqereqere dating to the past 2000 years group together, as they have low proportions of Scaridae and contain a balance of other herbivores/omnivores (Acanthuridae, Diodontidae) and carnivores (Lethrinidae, Lutjanidae, Serranidae). In the main cluster, fish bone from the two Lapita deposits of Votua (2000) and Kulu Bay are placed together away from the Votua 1996 and Navatu Layers 1-2 and Layer 4 assemblages. Interestingly, 
Kulu Bay and Votua 2000 were the only assemblages recovered by water sieving, and although Kulu Bay has a greater number of taxa than Votua 2000 (Kulu Bay=15 families, Votua 2000=6 families), they both have a primary emphasis on herbivores/omnivores (Scaridae, Acanthuridae, Diodontidae) and a secondary focus on carnivores (Labridae, Lethrinidae, Serranidae). The Navatu and Votua 1996 excavations sampled sediments that did not sieve easily, and the grouping of these two assemblages might indicate a potential bias against remains from small individuals, especially those of Scaridae. An alternative is that environmental differences were responsible for the low proportion of Scaridae at Volivoli II and Malaqereqere, pointing to the absence of shallow reef environments along the south coast of Viti Levu, compared with the prehistoric marine environment at Votua, Kulu Bay and Navatu. However, such potential environmental differences are not clearly reflected in the molluscan remains (see Chapter 8). Although Volivoli II is complicated by the dominance of terrestrial snails and opercula from an unidentified species of Turbo which may derive from either a rocky or reef-flat environment, Malaqereqere has a wide range of shellfish species from rocky and reef-flat environments that occur in some numbers.

The EPF fish-bone results were also compared with other Lapita and post-Lapita fish assemblages from Fiji to examine geographic and temporal variation in prehistoric fishing. Although Fowler (1955) recorded fish bone from 20 species and several genera from the Navatu site, his identifications require verification as in most instances Pacific fish bone can currently be reliably attributed only to the family level (Leach 1986; Nagaoka 1994). At the Yanuca rock-shelter site (VL 16/81), Hunt (1980) recorded 18 individuals and three families (Scaridae, Diodontidae, Serranidae), while at Naigani (VL 21/5), an approximate MNI of 18 was dominated by the Lethrinidae at 60\%, with the Scaridae at only 5\% (Best 1981:17). On Lakeba Island, fish bone analysed from sites 197, 196 and 47 suggests an early Lapita emphasis on the Lethrinidae (carnivores) and the Balistidae (omnivores), followed by an increase in the MNI of the Scaridae (herbivores), Diodontidae (omnivores) and Labridae (carnivores) and a decrease in the Lethrinidae and Balistidae (Best 1984). The view of prehistoric fishing from Lakeba is one of little change in the main taxa taken, but this is combined with an increase in the number of taxa taken over time. In the three lowest levels of the Lakeba 197 site, dating to ca. 2850-2900 cal. BP, there were only nine fish families, compared with 21 families in the three uppermost levels, dating to the past 500 years. At the Qaranicagi rock shelter (Y2-39) on Waya Island in the Yasawas, Hunt et al. (1999) report a fish-bone assemblage consisting of 70

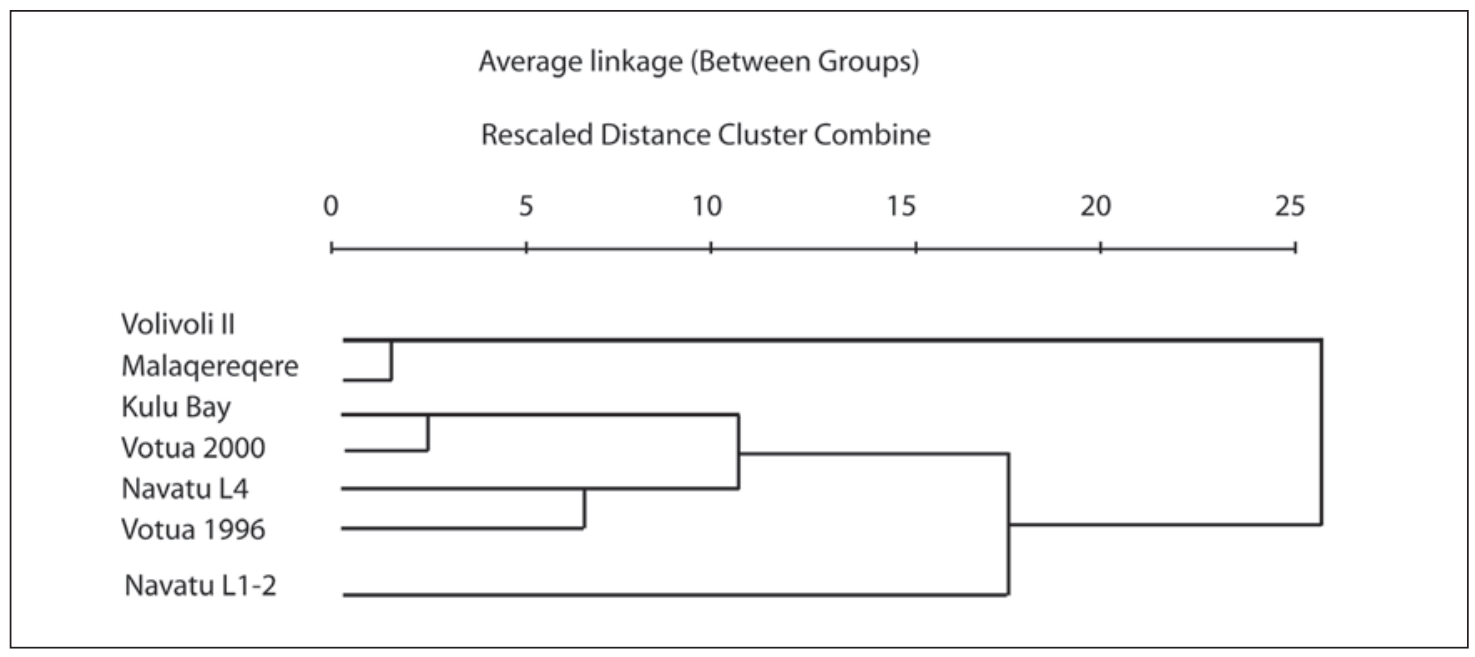

Figure 113. A hierarchical cluster analysis (HCA) of EPF fish-bone assemblages based on MNI\%. 
bones that were identified to 14 families, dominated by the Acanthuridae, Scaridae, Balistidae, Diodontidae and Labridae, repeating the mix of omnivores/herbivores and carnivores found in several EPF sites.

Lapita-era fish bone identified from Naitabale on Moturiki Island, reported by Nunn et al. (2007), was, in decreasing order of abundance, from the Scaridae, Lethrinidae, Serranidae, Diodontidae and Lutjanidae families. The Lapita levels of sites on Cikobia reported by Leach et al. (2000) were reanalysed by Hawkins (2000:46), and showed an emphasis on the Scaridae, Acanthuridae, Ostraciidae and Diodontidae, which can all be caught with non-angling techniques, along with a minor emphasis on carnivorous fish such as the Labridae, Lethrinidae and Serranidae, often caught by angling. However, in the two Aiwa Islands in the Lau Group, the Aiwa 1 site fish bone NISP of 2111 represented 19 families, dominated, in order, by the Serranidae, Acanthuridae, Balistidae, Scaridae, Diodontidae, Labridae and Lethrinidae, which was different from the Dau rock shelter (NISP=1575, 14 families) and Cave 2 assemblage (NISP=1180, 17 families), where the Scaridae and Acanthuridae were the main taxa taken (O'Day et al. 2003). A summary of fish bone from 12 sites on Nayau Island in the Lau Group based on \%NISP (Jones et al. 2007) indicates that the Scaridae (8\%) were less important than the Acanthuridae (34\%), Balistidae (19\%) and Diodontidae (16\%). Another site in the Lau Group, the Qaranilaca Cave on Vanuabalavu dating to the second millennium BP, had a fish bone NISP of 1073 from at least 16 families, with the Scaridae and Carangidae having the highest MNI, followed by the Labridae, Balistidae, Lethrinidae and Serranidae.

The main fish taxa in each assemblage vary widely in the proportion of carnivores relative to omnivores/herbivores, with several sites of Lapita and post-Lapita age containing a significant proportion of carnivores (Lakeba site 197 (basal levels), Aiwa 1, Naitabale). Such sites contrast with those where the Scaridae are dominant (Votua 2000, Kulu Bay, Navatu Layer 4) and those where there is a relatively even balance of carnivores and herbivores/omnivores (Volivoli II and Malaqereqere). The Qaranilaca site in northern Lau is unusual for the proportion of carangids, which combined with individuals of the Lethrinidae, suggests targeting of these taxa (Thomas et al. 2004).

The proportions of carnivores and omnivores/herbivores vary between Lapita sites, and geographic location and the local marine environment are the most likely causes (see Davidson et al. 2002; O'Day et al. 2003:47). The Votua 2000 assemblage was dominated by the Scaridae (40.4\%), while at Naigani, lethrinids were the main taxon caught (42.8\%), as at Lakeba site 197, where the basal levels were dominated by the Lethrinidae. It is notable that despite the difference in the main taxa taken (Scaridae versus Lethrinidae), the same shell fish hooks and arrow/spear smoothing coral abraders were found at Votua (Mago Island) and Lakeba, suggesting the technology was suitable for taking the variety of taxa common to nearshore environments. Over time, there is evidence for a greater number of fish taxa being taken, which could represent the increasing use of traps, nets and community fishing strategies in the post-Lapita period, as well as the targeting of families found at particular locations (e.g. Aiwa 1, Qaranilaca).

Given the results of shell-midden analysis in which freshwater species figure consistently in low numbers, as well as data from modern Fijian fisheries (e.g. see Rawlinson et al. 1994:Chapter 5), the lack of freshwater and/or estuarine fish and eels is perhaps surprising. However, there may be several interlocking factors at play here. Firstly, the Archaeology and Natural History fishbone reference collection is focused on marine taxa, meaning that freshwater fish bones may not have been identified. Secondly, some of the freshwater fish that contribute so strongly to modern catches, such as the jungle perch (Kublia rupestris) and tilapia (Oreochromis mossambicus), are modern introductions to Fiji. Thirdly, many of the native fish species common to freshwater/ 
estuarine niches fall into predominantly marine families that have been identified (e.g. Lutjanus argentimaculatus in the Lutjanidae). Thus, without species-level identifications, the potential importance of this ecological zone may have been obscured. Lastly, the use of different capture methods appears to strongly influence catch composition, with a creel survey conducted by Rawlinson et al. (1994:47) demonstrating that although the eel Anguila obscura was a preferred and apparently targeted taxon, the predominant use of gillnetting meant it did not feature strongly in actual catch data.

There is no doubt that an ability to identify fish bones beyond family level would greatly enhance our ability to discuss capture strategies, patterning in the exploitation of different environmental zones, economic structure and any tendency towards specialisation. Studies conducted elsewhere certainly demonstrate the utility of a more fine-grained, identificationdriven approach (e.g. Cooke 1992 for the tropical Pacific coast of the Americas; Leach and Boocock 1995; Leach et al. 1996, 1997 for New Zealand). There are clearly many obstacles to achieving this, given the variety of fish in the tropical Indo-West Pacific and the fact that species within some families (such as the Scaridae) can be difficult to accurately identify, even when alive. In addition, as pointed out above as well as by Vogel (2005), our reference collections need to be able to support these refinements.

Modern-day studies derived from fisheries and resource management can give insights, especially by pin-pointing species common at particular Pacific locales, thereby indicating a 'first port of call' in a reference collection. Johannes and MacFarlane (1991:120), in their study of traditional fishing in the Torres Strait Islands, point out that although they recorded the capture of more than 75 species during the course of their study, only five species contributed nearly $86 \%$ of overall catches. Similar conclusions are presented throughout Dalzell et al. (1996), who also observe that different species within the same family can dominate catches from island to island. For example, Dalzell et al. (1996:415) note that modern lethrinid catches from inshore fisheries around Fiji are dominated by Lethrinus nebulosus, while at Tikehau Atoll in French Polynesia, the dominant lethrinid is L. miniatus. Such geographic patterning is noted for the Lutjanidae, Acanthuridae and Serranidae, as well (Dalzell et al. 1996).

Despite the family-level identifications, what the various EPF assemblages tell us very clearly is that a range of capture techniques were employed from the Lapita period onwards. What remains of the actual prehistoric fishing technologies also suggests that generalised, versatile fishing gear was used. These results are in strong agreement with the molluscan remains, which point to a generalist gathering strategy involving taking a range of species from a variety of littoral niches. Further refinement of fish-bone identifications would allow us to explore issues of change and patterning in capture techniques, economic specialisation and the targeting of various niches, and is a clear agenda for the future. 


\section{References}

Allen, G. 2002. Marine fishes of tropical Australia and South-East Asia. Third edition. Western Australian Museum, Perth.

Allen, M.S. 1992. Temporal variation in Polynesian fishing strategies: The Southern Cook Islands in regional perspective. Asian Perspectives 31: 183-204.

Barnett, L.A. 1978. Manual for the identification of fish bones: A guide to the comparative skeletal collection in the Department of Prehistory. Department of Prehistory, Research School of Pacific Studies, Australian National University, Canberra.

Best, S. 1981. Excavations at Site VL 21/5 Naigani Island, Fiji, a preliminary report. Unpublished report, Department of Anthropology, University of Auckland.

Best, S. 1984. Lakeba: The prehistory of a Fijian Island. Unpublished PhD dissertation. Department of Anthropology, University of Auckland.

Burley, D.V. and Shutler, R. Jr. 2007. Ancestral Polynesian fishing gear: Archaeological insights from Tonga. In: Anderson, A., Green, K. and Leach, F. (eds), Vastly ingenious: The archaeology of Pacific material culture in honour of Janet M. Davidson, pp. 155-172. University of Otago Press, Dunedin.

Butler, V.L. 1988. Lapita fishing strategies: The faunal evidence. In: Kirch, P.V. and Hunt, T.L. (eds), Archaeology of the Lapita cultural complex: A critical review, pp. 99-115. Thomas Burke Memorial Washington State Museum research report No. 5. Burke Museum, Seattle.

Butler, V.L. 1994. Fish feeding behaviours and fish capture: The case for variation in Lapita fishing strategies. Archaeology in Oceania 29: 81-90.

Carcasson, R.H. 1977. A field guide to the coral reef fishes of the Indian and West Pacific Oceans. William Collins and Sons, Glasgow.

Chaplin, R.E. 1971. The study of animal bones from archaeological sites. Seminar Press, London.

Clark, G., Anderson, A. and Matararaba, S. 2001. The Lapita site at Votua, northern Lau Islands, Fiji. Archaeology in Oceania 36: 134-145.

Cooke, R. 1992. Prehistoric nearshore and littoral fishing in the eastern tropical Pacific: An ichthyological evaluation. Journal of World Prehistory 6(1): 1-49.

Coutts, P.J.F. 1975. Marine fishing in archaeological perspective: Techniques for determining fishing strategies. In: Casteel, R.W. and Quimby, G.I. (eds), Maritime adaptations of the Pacific. Moulton Publishers, The Hague and Paris.

Dalzell, P., Adams, T.J.H. and Polunin, N.V.C. 1996. Coastal fisheries in the Pacific Islands. Oceanography and Marine Biology: An Annual Review 34: 395-531.

Davidson, J., Hinds, E., Holdaway, S. and Leach, F. 1990. The Lapita site of Natunuku, Fiji. New Zealand Journal of Archaeology 12: 121-155.

Davidson, J., Leach, F. and Sand, C. 2002. Three thousand years of fishing in New Caledonia and the Loyalty Islands. In: Bedford, S., Sand, C. and Burley, D. (eds), Fifty years in the field, pp. 153-164. New Zealand Archaeological Association Monograph.

Dye, T. and Steadman, D.W. 1990. Polynesian ancestors and their animal world. American Scientist 78: 207-215.

Fowler, H.W. 1955. Archaeological fish bones collected by E.W. Gifford in Fiji. Bernice P. Bishop Museum Bulletin 214.

Froese, R. and Pauly, D. (eds) 2009. Pseudobalistes flavimarginatus. In: FishBase World Wide Web Electronic Publication; www.fishbase.org, version (03/2009) URL: http://www.fishbase.org/Summary/

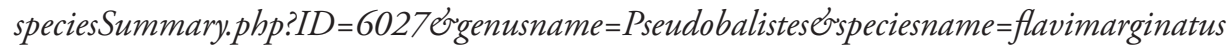

Gillett, R. and Moy, W. 2006. Spearfishing in the Pacific Islands: Current status and management issues. Secretariat of the Pacific Community, Noumea.

Grayson, D.K. 1984. Quantitative Zooarchaeology. Academic Press, New York.

Green, R.C. 1976. Lapita sites in the Santa Cruz Group. In: Green, R.C. and Cresswell, M.M. (eds), Southeast Solomon Islands cultural history: A preliminary survey. pp. 181-191. Royal Society of New Zealand Bulletin No. 11. 
Green, R.C. 1986. Lapita fishing: The evidence of site SE-RF-2 from the main reef islands, Santa Cruz Group, Solomons. In: Anderson, A.J. (ed), Traditional fishing in the Pacific, pp. 119-135. Pacific Anthropological Records 37. Honolulu, Hawaii.

Hawkins, S.C. 2000. Voyagers and fishermen: Early prehistoric fishing on Naigani Island, Fiji. Unpublished MA thesis, University of Auckland.

Hunt, T.L. 1980. Towards Fiji's past: Archaeological research on southwestern Viti Levu. Unpublished MA Thesis. Department of Anthropology, University of Auckland.

Hunt, T.L., Aronson, K.F., Cochrane, E.E., Field, J.S., Humphrey, L. and Rieth, T.M. 1999. A preliminary report on archaeological research in the Yasawa Islands, Fiji. Domodomo 12(2): 5-43.

Johannes, R. 1981. Words of the lagoon: Fishing and marine lore in the Palau District of Micronesia. University of California Press, Berkeley.

Johannes, R. E. and MacFarlane, J. W. 1991. Traditional fishing in the Torres Strait Islands. CSIRO Division of Fisheries Hobart, Australia.

Jones, S., Steadman, D. and O'Day, P. 2007. Archaeological investigations on the small island of Aiwa Levu and Aiwa Lailai, Lau Group, Fiji. Journal of Coastal and Island Archaeology 2: 72-98.

Kirch, P.V. and Dye, T. 1979. Ethno-archaeology and the development of Polynesian fishing strategies. Journal of the Polynesian Society 88: 53-76.

Kirch, P.V. and Yen, D.E. 1982. Tikopia: The prehistory and ecology of a Polynesian outlier. Bernice P. Bishop Museum Bulletin 238. Honolulu, Hawaii.

Kirch, P.V. 1988. Niuatoputapu: The prehistory of a Polynesian chiefdom. Thomas Burke Memorial Washington State Museum Monograph No. 5. The Burke Museum, Seattle.

Leach, B.F. 1986. A method for the analysis of Pacific Island fish bone assemblages and an associated data base management system. Journal of Archaeological Science 13(2): 147-159.

Leach, B.F. 1997. A guide to the identification of fish remains from New Zealand Archaeological Sites. New Zealand Journal of Archaeology Special Publication.

Leach, B.F. and Boocock, A. 1995. The estimation of live fish catches from archaeological bone fragments of the New Zealand snapper Pagrus auratus. Tuhinga: Records of the Museum of New Zealand 3: 1-28.

Leach, B.F., Davidson, J.M., Horwood, L.M., and Anderson, A.J. 1996. The estimation of live fish size from archaeological cranial bones of the New Zealand barracouta Thyrsites atun. Tuhinga: Records of the Museum of New Zealand 6: 1-25.

Leach, B.F., Davidson, J.M. and Horwood, L.M. 1997. The estimation of live fish size from archaeological cranial bones of New Zealand blue cod Parpercis colias. International Journal of Osteoarchaeology 7: 481-496.

Leach, B.F., Davidson, J.M., Fraser, K. and Budec-Piric, A. 2000. Analysis of faunal material from several archaeological sites on Cikobia, Fiji. Technical Report 28. Museum of New Zealand Te Papa Tongarewa.

Masse, B. 1986. A millennium of fishing in the Palau Islands, Micronesia. In: Anderson, A.J. (ed), Traditional fishing in the Pacific: Ethnographical and archaeological papers from the 15th Pacific Science Congress pp. 85-117. Pacific Anthropological Records No. 37, B.P. Bishop Museum, Honolulu.

Masse, B. 1989. The archaeology and ecology of fishing in the Belau Islands. PhD thesis, Ann Arbor Press, Michigan.

Nagaoka, L. 1994. Differential recovery of Pacific fish remains: Evidence from the Motrakau Rockshelter, Aitutaki, Cook Islands. Asian Perspectives 33: 1-17.

Nunn, P.D., Ishimura, T., Dickinson, W.R., Katayama, K., Thomas, F., Kumar, R., Matararaba, S., Davidson, J. and Worthy, T. 2007. The Lapita occupation at Naitabale, Moturiki Island, Central Fiji. Asian Perspectives 46(1): 96-132.

Ono, R. 2003. Prehistoric Austronesian fishing strategies: A comparison between Island Southeast Asia and the Lapita cultural complex. In: Sand, C. (ed), Pacific archaeology: Assessments and prospects. 
Proceedings of the New Caledonia 2002 conference, pp. 43-52. Les Cahiers de l'Archéologie en Nouvelle-Calédonie 15.

O'Day, S. Jones, O'Day, P., and Steadman, D.W. 2003. Defining the Lau context: Recent findings on Nayau, Lau Islands, Fiji. New Zealand Journal of Archaeology 25: 31-56.

Rawlinson, N.F.J., Milton, D.A., Blaber, S.M.J., Sesewa, A. and Sharma, S.P. 1994. A survey of the subsistence and artisanal fisheries in rural areas of Viti Levu, Fiji. Australian Centre for International Agricultural Research (ACIAR), Canberra.

Szabó, K. and Summerhayes, G. 2002. Worked shell artefacts - new data from early Lapita. In: Bedford, S., Sand, C. and Burley, D. (eds), Fifty years in the field, pp. 91-100. New Zealand Archaeological Association Monograph.

Szabó. K. 2007. An assessment of shell fishhooks of the Lapita cultural complex. In: Anderson, A., Green, K. and Leach, F. (eds), Vastly ingenious: The archaeology of Pacific material culture in honour of Janet M. Davidson, pp. 227-241. University of Otago Press, Dunedin.

Thomas, F.R., Nunn, P.D., Osborne, T., Kumar, R., Areki, F., Matararaba, S., Steadman, D. and Hope, G. 2004. Recent archaeological findings at Qaranilaca Cave, Vanuabalavu Island, Fiji. Archaeology in Oceania 39: 42-49.

Vogel, Y. 2005. Ika. Unpublished MA thesis. Department of Anthropology, University of Otago.

Walter, R. 1989. Lapita fishing strategies: A review of the archaeological and linguistic evidence. Pacific Studies 13: 127-149.

Walter, R. 1998. Fish and fishing. In: Walter, R. Anai'o: The archaeology of a fourteenth century Polynesian community in the Cook Islands, pp. 64-73. New Zealand Archaeological Association Monograph 22.

Williams, T. 1858[1985]. Fiji and the Fijians. The islands and their inhabitants. Fiji Museum, Suva. 